\title{
EKSISTENSI DIRI WARIA DALAM KEHIDUPAN SOSIAL DI TENGAH MASYARAKAT KOTA \\ (Fenomenologi Tentang Eksistensi Diri Waria Urbanisasi di Kota Malang)
}

\author{
Oleh: \\ Muhammad Ramadhana Alfaris ${ }^{1}$
}

\begin{abstract}
This research is a purpose to reveal how the self-existence of transvestites urbanization in Malang City. The methods used in this study using the method of transcendental phenomenology because this research is included in the phenomena of social life.

Self-existence of transvestites have a broad enough concept in a process which is the soul and the body is formed by imagination, emotion, and cognition. It can be said that a transvestite is the third human figure of absolute gender and the sexuality formed through pressure and socialization, then internalized into action normally, because of the sexuality orientation walks normally in accordance with the gender has been selected.
\end{abstract}

Kata kunci: eksistensi, kehidupan waria, eksistensialisme, fenomenologi

\section{PENDAHULUAN}

Eksistensi para kaum waria di tengah masyarakat kita bukan merupakan hal yang baru lagi meski tidak implisit ke dalam identitas gender normatif yaitu gender laki-laki dan perempuan, namun pada umumnya hampir setiap orang pasti mengetahui tentang sosok waria tersebut. Sederhananya adalah kaum waria kerap dikenali sebagai sosok individu yang memiliki jenis kelamin laki-laki akan tetapi berperilaku dan berjiwa seperti seorang perempuan yang hampir seutuhnya. Sejatinya, waria merupakan kelompok masyarakat yang minoritas, meskipun mereka tergolong minoritas tetapi pada kenyataannya kalau dipersentasekan menunjukan jumlah waria semakin lama semakin bertambah, terutama di kota-kota besar seperti kota Malang. Menurut penulis, waria secara universal merupakan fenomena yang menarik untuk dikaji, karena realitasnya tidak semua orang mampu mengetahui secara komprehensif dan memahami bagaimana dan mengapa sosok

\footnotetext{
${ }^{1}$ Dosen di Fakultas Hukum, Universitas Widyagama Malang
} 
waria dapat terbentuk dalam menjalani hirukpikuk kehidupan.

Berdasarkan fakta yang ada, bahwa citra dunia pelacuran khususnya waria tersebut menimbulkan stigma dari masyarakat sekitar, yang buntutnya berujung pada diskonfirmasi atas eksistensinya dalam berbagai faktor, seperti penyempitan kesempatan kerja untuk waria, saling bergunjing atas perilaku yang para waria lakukan, serta saling menuduh bahwa para kaum waria lah sosok yang membawa penyakit menular seksual yaitu penyakit HIV/AIDS. Situasi dan kondisi ini menjadi kompleks dan sulit untuk diputuskan kecuali pemerintahan setempat atau stakeholder dan pemangku kebijakan benar-benar serius memperbaikinya. Jadi atas hal ini pula membuat sangat sulit bagi masyarakat untuk kedepannya dapat mengakomodasi ruang bagi seorang waria dengan berbagai ragam citra atau stigma tadi terkecuali mereka para waria melakukan upaya-upaya ataupun strategistrategi khusus agar bisa mendapatkan tempat pada ruang sosial kehidupan bermasyarakat.

Sosok waria seutuhnya diterima atau ditolak dalam tatanan masyarakat akan sangat ditentukan dari bagaimana implementasi yang mereka lakukan di dalam eksistensinya dan bermasyarakat sehingga dapat menjadi bagian dari lingkungan sosial tersebut. Dalam artian seberapa besar kapabilitas dari seorang waria baik secara individual ataupun secara kolektif dalam perilaku kesehariannya.

Pada hakikatnya manusia merupakan makhluk individu yang memiliki jiwa dan akal di mana keduanya saling berhubungan erat yang nantinya akan menjadikan secara utuh seperti apa yang ingin manusia kehendaki, khususnya mengenai kehendak dalam bergender, di mana dapat kita ketahui bahwa gender tidak dibawa sejak lahir akan tetapi gender bisa berubah melalui sosialisasi. ${ }^{2}$ Oleh karenanya, banyak dari para kaum waria yang terkonformitas ketika mereka bersosialisasi dengan hubungan yang bersifat eksternal, dalam artian banyak faktor eksternal yang tentu dapat mempengaruhi, dapat diartikan mereka berperilaku terhadap orang lain sesuai harapanharapan para kelompok demi keberlangsungan hidupnya sendiri. Hal tersebut juga menunjukan bahwa manusia juga tidak bisa terlepas dari hubungan secara sosial yaitu hubungan kepada masyarakat sekitar dikarenakan manusia juga merupakan makhluk sosial, dalam artian bahwa manusia tidak hidup sendirian.

Kaum waria sebagaimana mestinya juga merupakan individu ataupun kelompok yang tidak lepas dari hubungan sosial dengan lingkungan sekitarnya. Dalam kehidupan sehari-harinya tentu saja para waria bersosialisasi dengan orang lain yang terlepas dari perilakunya yaitu terhadap masyarakat biasa lainnya, akan tetapi dari sekelompok masyarakat dengan ragamnya stratifikasi di masyarakat tersebut, tentu saja ada yang menerima para kaum waria tersebut dan ada juga yang tidak atau belum menerima kehadiran mereka. Hal tersebut merupakan suatu masalah atau problematika kehidupan sosial yang harus dipikul oleh para kaum waria dalam eksistensinya.

Dalam hal ini secara konsep waria merupakan salah satu bagian masyarakat yang

Krestan, 1995, dalam Sunarto, 2004. Pengantar

Sosiologi (Edisi revisi). FE UI. Jakarta, hal 111

98 | Eksistensi Diri Waria Urbanisasi... 
tengah mengalami proses sosialisasi dalam bereksistensi. Karena pada dasarnya manusia mengkonsepkan eksistensi diri melewati beberapa tahapan seperti imajinasi, emosi, kognisi, dan aksi yang harus bergerak bebas dari hubungan dunia untuk menuju eksistensi dirinya.

Waria yang tadinya berdiri secara individu seperti yang sudah disebutkan di atas bahwa mereka mencari teman yang sama dengan mereka dan senasib. Seperti yang diungkapkan Bierstedt dalam Sunarto (2004:126) bahwa kelompok kemasyarakatan merupakan kelompok yang hanya memenuhi satu persyaratan, yaitu kesadaran akan persamaan di antara mereka. Kalau kita menilik kepada kelompok waria tersebut ialah terjadi banyak kesamaan secara sadar, maka mereka tentu akan menyamakan visi dan misinya dalam bermasyarakat dengan tujuan untuk menutup sitgma yang muncul di permukaan oleh masyarakat. Pada akhirnya mereka membuat suatu komunitas atau kelompok kemasyarakatan yang personilnya jelas sama dan senasib sesuai dengan harapan mereka para kaum waria.

Jika menilik lebih jauh lagi mengenai waria, sesungguhnya kehidupan yang kaum waria alami sangat menyedihkan dan terpaksa dilakukan demi keberlangsungan hidupnya. Di samping itu krisis identitas mereka tidak hanya sebatas dari psikologi mereka saja melainkan dalam perilaku sosial mereka juga. Hal tersebut dapat menimbulkan banyak hambatan sosial guna mengaktualisasikan hubungan sosial pada umumnya atau bahkan hubungan sosial yang lebih luas lagi. Kesulitan mereka adalah dalam mengintegrasikan dirinya ke dalam struktur sosial masyarakat. Secara garis besarnya (Koeswinarno, 2004:25) sebenarnya waria harus dipandang dalam konstruksi sosial yang lebih jelas dan memiliki mkna dalam kehidupan sosial pada umumnya, yakni suatu upaya yang selalu dilakukan oleh kaum waria untuk dapat tetap eksis dalam kehidupannya.

Ada beberapa konsep gender pada bagian ini yang digunakan oleh sejumlah para ilmuwan sosial, seperti yang dikemukakan oleh Giddens (1989: 158 dalam Sunarto, 2004: 110) bahwa konsep gender menyangkut "The Psychological, social and cultural differences between males and females", yakni perbedaan psikologis, sosial, dan budaya antara laki-laki dan perempuan. Dalam artian, Giddens menekankan bahwa adanya perbedaan atas gender dari sisi psikologi, sosial, dan budaya karena sifatnya yang situasional. Sedangkan Lasswell (1987: 51 dalam Sunarto, 2004: 110) mengatakan bahwa gender terletak pada pengetahuan dan kesadaran, baik secara sadar ataupun tidak bahwa diri seseorang tergolong dalam suatu jenis kelamin tertentu dan bukan dalam jenis kelamin lain.

Peran gender (gender role) merupakan suatu hal yang berkenaan dengan aktifitas di mana laki-laki dan perempuan terlibat dalam suatu hal dengan gelombang yang berbeda. Robert Brannon (1996) membahas dari segi konsep peran. Dalam artian, Brannon menganggap peran merupakan bagian dari drama yang sedang diperankan oleh seseorang. Oleh karenanya, peran gender laki-laki atau peran gender perempuan adalah seperti sebuah script atau naskah dimana laki-laki serta perempuan yang ikut memenuhi bagian yang tepat dalam bertindak maskulin atau feminin (Brannon, 1996). Sedangkan menurut Brannon pengertian peran gender (gender role) adalah serangkaian kegiatan sosial yang signifikan 
terkait dengan laki-laki atau perempuan (Brannon, 1996, p.193). ${ }^{3}$

Pada dasarnya setiap manusia hidup pasti akan memiliki sebuah konsep diri (self concept) yang dibuat untk menjalani kehidupannya secara individual dan juga dalam tatanan sosial. Seiring berjalannya waktu konsep tersebut akan matang sesuai dengan yang manusia inginkan. Seperti yang diungkapkan oleh Rahmat (1996: 125) bahwa konsep diri adalah pandangan dan perasaan kita, persepsi ini boleh bersifat psikologis, sosial dan psikis. Konsep diri bukan hanya gambaran deskriptif, tetapi juga penilaian kita. Konsep diri didefinisikan secara umum sebagai keyakinan, pandangan atau penilaian seseorang, perasaan dan pemikiran individu terhadap dirinya yang meliputi kemampuan, karakter maupun sikap yang dimiliki individu. Didukung juga oleh Hurlock (1990:58) yang mengatakan bahwa konsep diri adalah gambaran yang dimiliki orang tentang dirinya. Konsep diri ini merupakan gabungan dari keyakinan yang dimiliki individu tentang mereka sendiri yang meliputi karakteristik fisik, psikologis, sosial, emosional, aspirasi dan prestasi. Kemudian Stuart dan Sudeen (1998 dalam Sunaryo, 2004), konsep diri adalah semua ide, pikiran, kepercayaan dan pendirian yang diketahui individu tentang dirinya dan mempengaruhi individu dalam berhubungan dengan orang lain.

Dari beberapa ulasan para ahli di atas mengenai tentang definisi konsep diri (self concept), maka dapat disimpulkan bahwa konsep diri adalah cara pandang secara

3 Dalam jurnal e-komunikasi. Renny Amelia. Konten Male Gender Role Dalam Film Animasi Walt

Disney. Universitas Kristen Petra Surabaya komprehensif tentang diri manusia itu sendiri yang meliputi kemampuan, perasaan, kondisi fisik serta lingkungan sekitar dalam bersosialisasi. Dalam artian, diri kita sendiri memahami betul jiwa yang kita miliki dalam melakukan tindakan dan juga dalam menjalani kehidupan. Kendati demikian, dalam hal ini, kaum waria telah mengkonsep dirinya sendiri secara sadar atas keputusannya sendiri. Dari kategori kemampuannya mereka memahami betul seperti apa kemampuan seorang wanita, kemudian perasaan mereka pun juga ikut masuk ke dalam jiwanya, di mana perasaan lembut atau lainnya yang dimiliki oleh perempuan itu terintegrasi pada diri para waria tersebut. Setelah fase-fase tersebut di jalani, maka fase berikutnya menuju kepada kondisi fisik, dalam hal ini kondisi fisik para waria juga sudah jelas sangat melekat karena untuk melengkapi karakteristik perempuan dalam fisik laki-laki.

Berbicara mengenai eksistensi jelas tidak jauh dari ranah kefilsafatan. Dalam Abidin (2014: 33-34) di mana istilah eksistensi berasal dari $(e k s=$ keluar, sistere $=$ ada atau berada). Dengan demikian, eksistensi memiliki arti sebagai "sesuatu yang sanggup keluar dari keberadaannya" atau"sesuatu yang melampaui dirinya sendiri". Dalam artian hanya manusia yang mampu melampaui dirinya sendiri dari keterbatasan biologis dan lingkungan fisiknya, yakni berusaha untuk tidak terkekang oleh segala batasan-batasan yang dimilikinya. Jadi pasalnya para eksistensialis menyebut manusia itu sebagai suatu proses "menjadi" yang bergerak aktif dan dinamis.

Sartre yang menekankan kepada kebebasan, sedangkan Heidegger menekankan 
kepada otentik yang meliputi tema-tema kebebasan, kecemasan, kematian, dan lain sebagainya. Jika dipadukan, kehidupan otentik di sini adalah keaslian dalam hidup dengan segala konsekuensinya atas apa yang manusia pilih dalam menjalani kehidupannya, berangkat dari hal tersebut akan menimbulkan konsekuansi baru yakni bertanggung jawab atas kebebasan yang diselimuti oleh tema-tema yang otentik yakni: (1) Kesadaran, dalam hal ini Sartre memiliki konsepsi tentang kesadaran. Dia memperluas pengertian kesadaran dengan cara membedakan antara kesadaran reflektif dan kesadaran pra-reflektif. Kesadaran prareflektif adalah kesadaran yang langsung terarah pada objek perhatian kita (objek seharihari maupun objek pemikiran atau objek penelitian), tanpa kita sendiri untuk merefleksikannya. Kemudian kesadaran reflektif adalah kesadaran yang membuat kesadaran pra-reflektif menjadi tematik atau dengan kata lain kesadaran yang membuat kesadaran yang tidak disadari menjadi disadari. (2) Karakter Negatif Kesadaran, menurut Sartre kesadaran merupakan sumber yang menciptakan ketiadaan. Dalam artian, wujud sebenarnya dari ketiadaan adalah ketidakhadiran dari bagian-bagian yang hilang dalam totalitas Ada. Akan tetapi apa yang hilang dalam totalitas Ada sebenarnya tidak bersumber dari Ada itu sendiri, melainkan dari negativitas kesadaran, yakni dalam perbuatan "menidak" terhadap Ada. Karena bagi Sartre, Ada itu sendiri adalah penuh, padat, dan melimpah-ruah sehingga tidak ada tempat bagi ketiadaan. Ketiadaan adalah sesuatu yang mendunia dan terbentuk karena harapanharapan yang berasal dari kesadaran. (3) Kebebasan, telah diketahui bahwa Sartre menyatakan bahwa manusia merupakan makhluk yang memiliki kebebasan (yang juga dimaknai sebagai kesadaran oleh Sartre) guna sebagai modal dasar. Dalam hal ini, pendirian Sartre tentang kebebasan dapat dikatakan cukup ekstrim, yakni kesadaran manusia terlepas dari relasi-relasi kausal yang mengukungnya. Oleh karenanya, Sartre menuliskan bahwa untuk menjadi dirinya sendiri, kesadaran harus bebas terlebih dahulu dari kausalitas tersebut. (4) Kecemasan, kalau manusia identik dengan kebebasan maka jaminan keberadaan dan keberlangsungan hidup diri dan eksistensinya tergantung pada kebebasannya. Seperti yang diungkapkan oleh Heidegger bahwa eksistensialisme pada manusia terhubung dengan tema otentik yang di antaranya ialah kecemasan (ketiadaan). Kebebasan dan tanggung jawab sebenarnya bukan sesuatu yang menggembirakan atau menyenangkan. Melainkan dapat menimbulkan kecemasan, karena pada dasarnya kecemasan adalah gejala universal dan bisa menyerang siapa saja, ketika manusia itu sendiri memiliki kebebasan dan tanggung jawab. (5) Malafide, dalam malafide ini adalah kenyataan yang tidak diakui atau ditutup-tutupi, dengan kata lain manusia menipu dirinya sendiri dengan cara menyangkal kebebasannya dan menutupi kecemasannya. Malafide (bad faith) atau keyakinan yang buruk ini adalah bukti dari adanya kesadaran akan kebebasan dan kecemasan kita (Abidin, 2014: 198-203).

\section{METODE}

Metodologi pada penelitian ini dilakukan dengan menggunakan pendekatan kualitatif yang lebih menekankan pada proses. Dalam buku Sugiyono, metode penelitian kualitatif sering disebut metode penelitian naturalistik karena penelitiannya dilakukan pada kondisi yang alamiah (natural setting). 
Dalam penelitian kualitatif instrumennya adalah orang atau human instrument, yaitu peneliti itu sendiri ${ }^{4}$. Sedangkan menurut Bungin dalam bukunya penelitian kualitatif menyatakan bahwa penelitian kualitatif adalah penelitian yang bersifat studi kasus, yang bertujuan untuk menggambarkan, meringkas berbagai kondisi, berbagai situasi, atau berbagai fenomena realitas sosial yang ada dalam masyarakat yang menjadi objek penelitian yang berupaya menarik realitas itu kepermukaan sebagai suatu ciri, karakter, sifat, model, tanda, atau gambaran tentang kondisi, situasi, ataupun fenomena tertentu ${ }^{5}$. Senada dengan metode penelitian, di samping menggunakan pendekatan kualitatif, penelitian ini menggunakan metode penelitian fenomenologi tidak dapat dilepaskan dari metode penelitian kualitatif dan juga tidak dapat dilepaskan dari hubungan antara realitas fisik dan realitas psikis manusia. Seperti yang telah diketahui bahwa fenomenologi merupakan peralihan subjektif yang menjadi ciri semua pemikiran modern dan menyadarkan wawasan bahwa kesadaran manusia terperangkap dalam sebuah sistem representasirepresentasi referensial diri (Ritzer, 2011: 460).

Selanjutnya, metode penelitian fenomenologi berujuan untuk mengetahui dunia dari sudut pandang orang yang mengelaminya secara langsung atau sangat erat berkaitan dengan sifat-sifat yang alami dari pengalaman manusia, dan makna yang ditempatkannya (Kuswarno, 2009: 35-36). Husserl menekankan bahwa metode penelitian fenomenologi bertugas untuk menjelaskan banyak hal yang ada di dalam diri (things in

4 Sugiyono, 2011, "Metode Penelitian Kuantitatif, Kualitatif, dan R\&D”, Bandung, hal. 8 themeselves), yakni mengetahui apa yang masuk sebelum kesadaran, kemudian memahami makna dan esensinya, dalam intuisi dan refleksi diri. Proses fenomenolgi ini juga merupakan penggabungan dari apa yang nampak atau jelas dan apa yang ada dalam gambaran orang yang mengalaminya secara langsung. Dengan demikian, peneliti secara langsung menginternalisasikan dari empirik objek tersebut untuk memperoleh hasil yang akurat dalam fenomenologi (Kuswarno, 2009:40). Husserl menamakan proses tranformasi dari pengalaman empiris ke makna esensi adalah "ideation" dalam fenomenologinya. Dalam ideation ini, objek yang muncul dalam kesadaran kemudian terintegrasi pada objek itu sendiri, dengan tujuan untuk menemukan makna yang dijadikan dasar bagi pengetahuan.

\section{HASIL DAN PEMBAHASAN}

\section{A. Eksistensi Diri Waria Kota Malang}

Kaum waria tengah mengalami gejolak eksistensi pada dirinya, yaitu dalam aspek kebebasan, kecemasan, dan kehidupan. Dalam aspek kebebasan yakni pada dasarnya para kaum waria memiliki hak untuk kehidupannya. Berangkat dari hal tersebut, tentu saja semua keputusan-keputusan yang diambil pasti akan ada sebab akibat atau risiko-risiko yang akan terjadi kedepannya. Di mana kehidupan waria selalu saja ada konflik internal maupun eksternal yang membuat kecemasan dalam menjalani kehidupan. Meskipun kecemasan itu selalu dihadapi oleh para kaum waria, mereka pun sudah bisa memahami, mengantisipasi, bahkan mengpreventifkan atas kecemasan yang mereka rasakan berdasarkan aspek kehidupan,

5 Bungin, 2008. Penelitian Kualitatif. Jakarta, hal 68

102 | Eksistensi Diri Waria Urbanisasi... 
karena pada dasarnya keputusan bebas yang mereka pilih tersebut untuk kehidupannya semata.

\section{a) Kesadaran}

Para waria Malang telah merefleksikan secara matang tentang pilihan menjadi seorang waria. Berangkat dari hal tersebut beberapa waria Kota Malang mengalami kedua fase tersebut. Waria yang menghadapi fase kesadaran pra-reflektif adalah ketika sejak lahir berkelamin laki-laki akan tetapi sejak kecil memang memiliki hasrat seksual yang lebih tinggi kepada laki-laki, kemudian dirinya langsung menyadari bahwa dirinya adalah seorang wanita. Perilaku lemah gemulai yang sangat kental dengan wanita yang dilakukan oleh para waria ketika mereka bersosialisasi kepada masyarakat sekitar juga merupakan bagian dari kesadaran reflektif, dalam artian mereka sadar bahwa diri dan jiwanya adalah seorang wanita oleh karenanya perilaku mereka harus secara totalitas menjadi seorang wanita, seperti gerak jalannya, tutur kata yang lembut layaknya seorang wanita pada umumnya selama mereka bersosialisasi kepada masyarakat sekitar, kerabat, dan teman sesamanya. Kesadaran pra-reflektif yang terjadi oleh para kaum waria juga dibenarkan dalam bidang kelainan seks sejak dini bahwa kaum waria memiliki hasrat seksual yang lebih tinggi dengan laki-laki ${ }^{6}$.

Tema kesadaran yang mereka alami dalam eksistensi diri tersebut juga meliputi berbagai perspektif yang khususnya dalam perspektif sosial. Ketika fase pertama waria telah menyadari akan pilihannya menjadi seorang wanita berbadan laki-laki tentu saja akan

${ }^{6}$ Kelainan hasrat seksual waria lebih tinggi kepada laki-
laki dikutip dari hasil penelitian tesis Elizabeth Koes
Soedijati, 1996. Adaptasi dan Konflik dalam kehidupan megalami beberapa hambatan sosial yang di antaranya adalah penolakan dari masyarakat dan keluarga. Pada kesadaran reflektifnya adalah kebalikan dari kesadaran pra-reflektif di mana waria kembali terfokus kepada proses menjadi, yakni kembali sadar bahwa dirinya seorang laki-laki.

Berdasarkan dari hasil wawancara yang ditemukan ialah semua informan lebih cenderung mengalami kesadaran pra-reflektif, dalam artian para informan merasa ada sisi kewanitaannya sejak dari kecil. Kesadaran tersebut juga didasari oleh pernyataan informan kepada peneliti bahwa sejak lahir lebih dominan hormon perempuan dari pada hormon laki-laki.

\section{b) Karakter negatif kesadaran}

Ketika berada di dalam kamar yang sunyi dan cahaya lampu yang remang-remang berwarna oranye, pakaian berserakan di sekitar kasur, dengan bangganya menunjukkan hasil rekaman bernyanyinya dengan suara yang merdu seperti seorang perempuan, hampir persis kelembutan suaranya seperti perempuan. Selama alunan musik berputar nada suara indahnya tetap konsisten mengikuti irama musik. Suara lembut yang keluar dari mulutnya dalam nyanyian merupakan karakter negatif kesadaran yang hampir utuh dalam eksistensinya.

Bukan hanya sampai di situ saja, orderan job menyanyi pun juga banyak didapatkan karena bermodalkan suara merdu khas perempuan. Hingga pada saat di mana ada sebuah acara pertemuan yang mengharuskan untuk bernyanyi di acara tersebut. Kemolekan tubuhnya yang indah dihiasi pakaian ketat

Waria (Tinjuauan Tentang Dunia Sosial Waria di Kotamadya Bandung). Universitas Padjadjaran: Bandung 


\section{WIDYA YURIDIKA Jurnal Hukum Volume 1 / Nomor 1 / Juni 2018}

berwarna-warni dan sepatu high hils, perlahan menaiki panggung untuk bersiap-siap bernyanyi. Para tamu undangan langsung menolehkan kepala dan tertuju kepada sang penyanyi.

Hentakan alat musik mulai berlantun dan suara mrdunya mulai terdengar. Genre masik yang dinyanyikan adalah musik dangdut. Karena hentakan ketukan musik dangdut tersebut membuat badannya indah bergoyang untuk menghidur para tamu di acara tersebut. Seiring badan bergoyang, suara perempuan tetap konsisten sampai berakhirnya alunan musik.

Situasi tersebut terdapat ketidakhadiran dari bagian-bagian yang hilang dalam totalitas Ada dalam eksistensi yakni totalitas kewanitaannya menghilang ketika terjadi insiden penggerebekan dan mereka berlari layaknya seorang laki-laki. Hal tersebut menunjukkan bahwa terdapat ketiadaan atau ketidakhadiran (sifat laki-laki keluar secara spontanitas) dari totalitas Ada (kewanitaan). Bukan hanya pada situasi itu saja, bahkan terkadang secara spontanitas ketika beberapa waria berinteraksi secara sosial kepada masyarakat sekitar atau teman sesamanya, acap kali mereka mengeluarkan suara besar yang identik dengan suara laki-laki. Hal tersebut juga merupakan bagian dari karakter negatif kesadaran dalam eksistensi.

Tidak dapat dipungkiri lagi terkait dengan tema karakter negatif kesadaran yang dialami oleh informan. Berdasarkan fakta dan hasil wawancara dan hasil pengamatan menunjukkan bahwa semua informan masih memiliki karakter laki-laki sesuai kodratnya tersebut masih melekat dalam dirinya. Dalam artian masih terdapat ketidakhadiran atau menghilangnya totalitas Ada dari eksistensinya.

\section{c) Kebebasan}

Para waria Malang yang merantau sebelumnya adalah seorang laki-laki, seiring berjalannya waktu, mereka menemukan titik kebebasan yang menurutnya benar dan nyaman untuk kehidupannya. Mereka menggunakan imajinasi, emosi, kognisi, serta aksi yang terlepas dari kausal yang mengukung dirinya untuk memilih menjadi seorang wanita dengan fisik laki-laki. Dengan Imajinasinya yang selalu terbayang menjadi seorang wanita, kemudian menginternalisasikan jiwa kewanitaannya dengan emosi yakni didukung oleh hasrat seksual yang cenderung menyukai laki-laki, kemudian diaplikasikan dalam bentuk aksi yang matang dari pilihannya bahwa eksistensi kebebasannya adalah seorang wanita.

Kebebasan dalam eksistensi yang dipilih dalam artian mereka berupaya terus-menerus untuk menunjukkan kepada masyarakat luas bahwa mereka ada dan jelas dalam status sosialnya. Agar mereka tetap bebas dalam perilaku eksistensinya, sehingga terbentuk suatu kelompok atau komunitas yang berisikan para waria guna memperkuat eksistensi mereka di Kota Malang. Berangkat dari hal tersebut, didukung juga oleh masuknya budaya luar yakni isu LGBT yang beredar luas di masyarakat membuat mereka mengeluarkan suaranya dengan tujuan ingin membuat eksistensi mereka legal secara tatanan yang bersifat mainstream seperti agama, politik, hukum, dan budaya.

Pilihan menjadi waria merupakan pilihan yang sangat berat karena dalam eksistensi kebebasan harus membutuhkan tanggung jawab kepada dirinya sendiri dan juga orang lain. Ketika mereka memilih menjadi seorang waria maka mereka mempunyai tanggung jawab atas apa yang ia pilih. 
Bentuk tanggung jawab atas kebebasannya adalah mereka melakukan seperti sikap dan memiliki adab yang baik terhadap masyarakat sekitar dalam kesehariannya, kemudian mengikuti pelatihan atau program pemberdayaan yang dilakukan oleh pemerintah setempat guna mengembangkan potensi yang mereka miliki. Hal tersebut adalah bentuk tanggung jawab dalam kebabasan menjadi waria dalam bereksistensi.

Eksistensi kebebasan yang terjadi pada semua informan menyatakan bahwa memang para informan sangat merasa bebas dengan pilihannya menjadi waria. Dengan kata lain, setelah melewati beberapa proses eksistensi dari kesadarannya, fase ini merupakan bagian yang cukup penting dalam menentukan jati diri sebagai waria lantara kebebasannya terbentuk dari diri sendiri secara hakiki tanpa ada campur tangan dari wacana yang bersifat mainstream.

\section{d) Kecemasan}

Manusia pada umumnya pasti akan merasakan cemas atau ketakutan dalam eksistensi mereka, begitu pun para waria juga terdapat kecemasan yang mereka alami. Kecemasan itu muncul ketika mereka telah meyakini pilihan kemudian diimplementasikan kepada tindakan. Kecemasan-kecemasan yang dialami para waria adalah ketika keyakinan menjadi waria datang kemudian timbul kecemasan apakah terjadi penolakan dari keluarga, di samping itu apakah masyarakat sekitar bisa menerima mereka, kemudian kecemasan dalam hal mencari pekerjaan yang memang kecil kemungkinan mereka dapat diterima bekerja seperti orang normal pada umumnya. Sehingga tidak sedikit dari mereka yang melakukan pekerjaan negatif dan melanggar hukum seperti berprofesi menjadi seorang pekerja seks komersil (PSK). Dapat dikatakan hampir semua kecemasan para waria itu adalah keinginan mereka untuk dianggap Ada dalam eksistensinya.

Jika menilik lebih jauh lagi, kecemasan lainnya yang dialami oleh informan adalah berkaitan dengan emosi hati. Emosi hati di sini ialah perasaan dengan seorang laki-laki, dalam hal ini waria adalah perempuan yang membutuhkan pasangan untuk kehidupannya. Eksistensi kecemasan yang terjadi adalah merasa cemas dan takut untuk melakukan operasi total, yakni suntik payudara, dan operasi operasi kelamin karena belum ada sosok laki-laki yang ingin berhubungan serius dengan informan tersebut.

Kecemasan dalam bereksistensi yang mereka alami lebih cenderung kepada kecemasan dalam menyempurnakan tubuhnya sebagai layaknya seorang perempuan, yakni melakukan suntik dan operasi bagian tubuhnya. Kecemasan lainnya yang mayoritas dialami oleh waria ialah dalam hal memikirkan sampai berapa lama mereka harus menjadi waria. Di sisi lain dari kecemasan yang berkelanjutan itu juga terdapat dalam hal mencari pekerjaan, di mana memang sulit dan kecil kemungkinan mereka dapat diterima bekerja seperti orang normal pada umumnya.

\section{e) Malafide}

Jika menilik ke arah waria yakni seorang waria di jalanan, di mana semua gerakannya dan kelakuan waria itu sangat menyerupai wanita dan berlebihan. Ia membungkukkan badan dalam suatu cara yang begitu rupawan sehingga tampak penuh perhatian. Ia mempromosikan kemampuan dan servisnya dengan membusungkan dadanya ke arah konsumen dengan anggun layaknya wanita. Gerakannya seperti sebuah permainan. Permainan yang ia lakukan adalah permainan 
seorang wanita. Ia sangat sadar atas apa yang ia lakukan. Semua yang ia lakukan timbul dari keinginannya untuk membuat kondisi menjadi nyata. Jadi ia tidak punya pilihan lain, selain secara totalitas larut ke dalam kondisi menjadi seorang waria. Bukan hanya ia sendiri sebenarnya, melainkan tekanan dari luar pun menuntutnya untuk berbuat hal demikian.

Hal tersebut merupakan kondisi eksistensialis yang dihadapi para waria. Tidak sedikit dari para waria yang mengalami fase malafide karena mereka sadar bahwa mereka termasuk golongan minoritas dalam tatanan sosial, akan tetapi mereka tetap bersemangat untuk tetap eksis dalam tatanan sosial. Berangkat dari hal tersebut tindakan yang mereka ambil juga terdapat pengaruh tekanan eksternal seperti faktor keluarga, dan lebih khususnya faktor ekonomi yang membuat mereka melakukan hal yang ekstrim. Faktor eksternal yang cukup berpengaruh biasanya dari kondisi perekonomian waria, misalkan waria yang berprofesi sebagai Pekerja Seks Komersil (PSK), profesi ini merupakan profesi alternatif agar mereka mendapatkan income untuk kehidupan sehari-harinya karena mudah mendapatkan uang dan nafsu juga terlampiaskan. Jadi faktor ekonomi cukup berpengaruh menjadi tekanan eksternal dalam profesi PSK yang mereka lakukan.

Waria lebih cenderung mengalami kesadaran pra-reflektif dalam eksistensinya menjadi waria. Karakter negatif kesadarannya pun juga masih kerap terjadi yang menimbulkan sisi kebebasan yang utuh lahir dan batin. Namun, tidak menutup kemungkinan dari adanya kebebasan tersebut pasti terdapat kecemasan dan malafide yang berjalan berdampingan dalam eksistensi diri waria urbanisasi di Kota Malang.

\section{B. Kehidupan Sosial Waria Urbanisasi Kota Malang}

Seperti yang sudah dijabarkan di atas mengenai lima tema dalam eksistensialisme, bahwa sesungguhnya pergulatan kehidupan yang waria alami dapat dikatakan cukup berat karena harus memiliki peran ganda dalam kehidupannya. Setelah kebebasan yang dipilih sudah bulat dan matang, tentu saja akan ada tanggung jawab di dalamnya. Kedua hal tersebut menggerakkan kognisi yang membutuhkan pengetahuan untuk melengkapi kebebasannya.

Kognisi di sini adalah pemerolehan pengetahuan dalam eksistensi yang di pilihnya. Pengetahuan yang paling mendasar yang para informan miliki adalah pengetahuan tentang agama. Semua informan memiliki pengetahuan agama yang cukup untuk bekal dikehidupannya, seperti pengetahuan sejarah agama, akhlak, dan mengetahui tuntunan beribadah yang baik.

Pola pikir mereka tentang agama cukup memadahi, ketika duduk berdua dengan informan saling bertatap muka. Informan bercerita tentang sejarah Nabi Luth pada saat itu. Intonasi suara yang dikeluarkan juga cukup jelas tanpa terbata-bata, kemudian sambil memainkan alisnya naik dan turun membuat suasana semakin serius. Obrolan semakin hangat diiringi canda dan tawa, kemudian diungkapkannya kembali mengenai topik agama yang lebih detail seperti tuntunan dan kewajiban dalam beragama yakni shalat. Mereka dalam beragama selalu melakukan kewajibannya, seperti shalat lima waktu, shalat jumat, dan puasa, serta kebaikan-kebaikan kepada orang sekitar mereka sesuai dengan tuntunan agama. Akan tetapi mereka dapat 
memisahkan pengetahuan agama yang dimiliki dengan realitas pengaplikasiannya.

Eksistensi yang mereka pilih adalah sebagai waria atau perempuan, ketika menunaikan ibadah shalat mereka kembali ke kodrat asalnya sebagai laki-laki dengan berpakaian ibadah seperti sarung, dan peci tidak menggunakan mukena yang merupakan pakaian ibadah seorang perempuan pada umumnya. Sisi lainnya adalah seperti ungkapan-ungkapan agama, yakni alhamdulillah, astaghfirullah, ucapan basmalah, salam, dan ungkapan lainnya yang bersifat mainstream dalam agama kerap terjadi pada masing-masing informan. Katakata tersebut keluar secara otomatis ketika dalam kondisi yang mengharuskan mereka untuk mengucapkan kata tersebut.

Namun, pengetahuan agama yang mereka miliki hanya sebatas pengetahuan saja, dalam artian tidak terinternalisasi ke dalam jiwanya. Dalam kehidupan sosialnya secara norma agama mereka taat dan bersikap baik kepada orang lain. Tetapi ketika dalam hal yang bersifat materi mereka tidak memasukkan nilai agama di dalamnya. Karena bagi mereka dosa maksiat adalah urusan dirinya dengan Tuhan, walaupun mereka tidak mengerti kenapa Tuhan mendisain seksualitas ganda khususnya pada hormon, oleh karenanya mereka menerima atas semua yang telah terjadi kepada mereka adalah sebuah takdir yang diberikan oleh Tuhan, yang penting bagi mereka selalu bersikap baik kepada sesama manusia.

Permasalahan sosial seperti stigma dan diskriminasi merupakan peranan yang cukup penting dalam pembentukan konsep diri waria. Sejak masa kecil kita dicemooh, di anggap asing, ditertawai, kemudian didiskriminasikan di dalam rumah, di sekolah, lingkungan dan bahkan dalam komunitas yang bersifat mainstream, khususnya seperti agama.

Setiap informan yang peneliti wawancarai, dengan menjadi seorang waria kerap mendapati rekasi-reaksi sosial. Banyak ragam bentuk dari reaksi sosial tersebut kepada informan, bisa dikatakan ada reaksi sosial yang ringan dan juga berat. Reaksi tersebut bisa terjadi dari pihak keluarga, teman sebaya, dan masyarakat sekitar.

a) Keluarga. Kehidupan sosial keluarga yang dialami waria semuanya mendapat dukungan yang positif terhadap eksistensi menjadi waria. Hanya saja dukungan tersebut tidak secara mentah-mentah dilakukan oleh pihak keluarga melainkan terdapat pesan-pesan moral yang terkandung di dalam eksistensi diri. Berawal dari mitos jawa di mana kalau orang hamil tidak boleh membenci seseorang, jika membenci seseorang maka anak yang dilahirkan nanti akan seperti orang yang dibenci. Pada saat itu ayahnya membenci sekali dengan yang namanya waria, kemudian didukung juga oleh mbah kakungnya yang menginginkan cucu perempuan. Berangkat dari hal terebut realitas berkata sang anak lahir dengan hormon perempuan yang lebih.

Ketika terlahir secara tidak normal, awalnya orang tua tidak mengetahui persis sisi hormon yang dimiliki oleh seorang anak, akan tetapi ketika umur 4 tahun baru mulai kelihatan reaksi hormon wanita di dalam diri sang anak. Hal tersebut menggerakkan orang tuanya untuk kontrol secara klinis apa memang benar anaknya tersebut memiliki hormon perempuan yang lebih dari pada hormon laki-laki, hingga 
akhirnya memang benar positif lebih banyak hormon perempuan.

Para orang tua pada awalnya mengeluhkan dengan hasil yang didapati. Namun orang tuanya tetap melakukan upaya untuk menormalkan kembali diri sang anak seperti, memberikan mainan mobilmobilan dan lain sebagainya yang identik dengan mainan anak laki-laki. Upaya tersebut terus dilakukan oleh orang tua sampai anak lulus dari SD. Akan tetapi seiring pertumbuhan sang anak, hormon perempuannya pun juga ikut tumbuh sehingga upaya-upaya praktis tersebut tidak sama sekali membuahkan hasil. Bahkan sang anak pun menolak dengan upaya memberikan mainan tersebut. Sang anak lebih tertarik kepada mainan anak perempuan seperti boneka-bonekaan dan lain sebagainya yang identik dengan perempuan.

Seiring berjalannya waktu, dengan dorongan hormon perempuannya itu membuat terjadinya insiden negatif yang terjadi kepada sang anak, di mana sang anak mulai mengenal seks dan berhubungan seks sejak dini di bangku SD tanpa sepengetahuan orang tua dan sang anak pun tentu saja menutupi hal itu, lantaran perlakuan seks tersebut dilakukan oleh seorang guru olah raga di sekolah tersebut. Bukan berarti sang anak kecewa atau marah, melainkan hal tersebut jadi disukai karena dorongan hormon perempuan tersebut di mana sang anak lebih tertarik dan menyukai seorang lakilaki.

Namun dalam kesehariannya pihak orang tua selalu memperhatikan perkembangan sang anak secara bertahap. Banyak upaya orang tua dalam mendidik sang anak untuk menjadi normal, seperti mengedukasi sang anak seperti anak laki-laki pada umunya, memberikan permainan anak laki-laki. Namun, upaya yang orang tua lakukan tetap stabil dan tidak menunjukkan ke arah yang orang tua inginkan, bahkan ketika semakin besar tekanan dari normalisasi yang orang tua lakukan membuat sang anak menjadi depresi berat. Hingga pada akhirnya pihak orang tua mengembalikan semua keputusan tentang keinginan di dalam hati sang anak, yaitu menjadi seorang waria.

Ketika keputusan tersebut sudah bulat dari sang anak, upaya orang tua hanya bisa memberikan nasihat-nasihat yang positif kepada anak, seperti nasihat dalam aspek agama, sosial, dan lain sebagainya guna menunjang pemikiran sang anak untuk kedepannya. Hingga akhirnya sang anak pun hijrah ke kota-kota untuk mencari nafkah sendiri lantaran tidak mau membebani kedua orang tuanya.

b) Teman sebaya. Hampir mayoritas dari dari aspek teman sebaya tidak menjauhi informan melainkan semua temannya merangkul dan saling menghargai. Namun, sedikit dari teman informan yang mencela karena berada dalam satu ruang lingkup di dunia hiburan malam, seperti purel (wanita pemandu karouke) yang mencela waria karena waria tersebut termasuk dalam pesaing pekerjaan di dunia hiburan malam. Terdapat juga dari beberapa teman lakilakinya kerap melakukan pelecehan seksual kepada informan. Dalam artian, teman-teman laki-lakinya lebih cenderung memanfaatkan informan untuk memuaskan hasrat seksualitas teman laki- 
WIDYA YURIDIKA Jurnal Hukum Volume 1 / Nomor 1 / Juni 2018

lakinya tersebut. Pada dasarnya pelecehan tersebut termasuk ke dalam kategori negatif, namun menurut informan hal tersebut termasuk hal yang menyenangkan dan informan pun menyukainya.

c) Masyarakat sekitar. Respon masyarakat pada dasarnya bergerak secara fluktatif tergantung dengan situasi dan kondisi. Pada kondisi lain seperti ketika dalam bekerja, informan yang memiliki profesi sebagai penyanyi pun mendapatkan respon positif ketika berada dalam satu ruang pekerjaan yakni acara menyanyi. Masyarakat yang ada di dalam acara tersebut pun tidak menunjukkan tindakan negatif, seperti mencela informan.

Kehidupan sosial terhadap masyarakat sekitar memang pada dasarnya ada yang suka dan ada yang tidak suka. Namun fenomena tersebut dapat dikatakan tidak serta-merta selalu negatif, melainkan ada juga beranggapan positif kepada waria khusunya para informan. Dari ulasan di atas, klasifikasi kehidupan sosial waria urbanisasi di Kota Malang dapat dilihat pada tabel berikut ini:

Hampir mayoritas dari pihak keluarga informan memberikan respon yang positif, dalam artian semua orang tua informan mendukung atas eksistensi menjadi waria. Tidak berbeda jauh dengan teman sebayanya yang melihat secara objektif di mana infroman dihargai karena sikap dan potensi positif yang dimiliki informan. Namun berbeda dengan respon masyarakat sekitar informan. Masyarakat yang kerap mengucilkan informan yakni masyarakat kelas menengah ke atas. Berbeda dengan masyarakat kelas menengah ke bawah yang lebih merespon positif atas eksistensi dirinya menjadi waria.

\section{Upaya-upaya}

Eksistensi

Waria di Kota Malang merupakan fenomena yang kita ketahui dalam eksistensinya banyak bercorak negatif. Hampir sebagian dari banyaknya waria yang berada di Kota Malang adalah bukan waria yang memang asli penduduk Malang, melainkan banyak waria pendatang atau perantauan yang mengadu nasib di Kota Malang.

Domisili para waria terletak kota yang tentunya merupakan kota yang padat dengan penduduk, meskipun ada juga para waria di Malang yang berada di daerah kabupaten. Para waria tinggal di kost-kostan yang bebas, bebas di sini sepeti bebas jam malam, dan tidak terlalu banyak aturan. Kost-kostan yang mereka tempati berpenghuni dari beragam gender dan juga status sosial mulai dari laki-laki, perempuan, pasutri, dan juga waria.

\section{a. Organisasi}

Hampir mayoritas waria yang berada di Kota Malang memiliki organisasi. Organisasi di sini merupakan wadah dalam menjaga eksistensi. Upaya yang para informan lakukan adalah masuk ke dalam organisasi dengan tujuan kebebasan gender mereka dapat di akui di mata masyarakat luas. Karena pada dasarnya manusia tidak bisa hidup sendiri melainkan manusia merupakan makhluk sosial yang membutuhkan orang lain dalam kehidupannya. Khusunya para informan yang membutuhkan orang lain sesamanya.

Para waria berupaya masuk ke dalam organisasi tentu saja bukan hanya sebatas kumpul-kumpul yang tidak jelas, melainkan memiliki visi dan misi yang dituju oleh organisasi tersebut, di mana tujuan utama organisasi tersebut adalah untuk mengangkat 
nama waria dan melegalitaskan gender mereka sebagai waria.

Terdapat juga beberapa organisasi-organisasi yang bertema gender di Kota Malang di mana para informan penelitian ikut di dalamnya, seperti:

a) IWAMA (Ikatan Waria Malang).

b) WAMARAPA (Waria Malang Raya Peduli Aids).

c) Lembaga IGAMA (Ikatan Gaya Arema).

Keberadaan para waria di dalam organisasi tentu saja terdapat upaya-upaya yang bersifat kolektif. Dalam hal ini upaya mempertahankan eksistensi diri informan yang bersifat kolektif di organisasinya, seperti aktif dalam kegiatan olah raga volly. Keaktifan dalam olah raga volly membuat informan menjadi lebih dihargai oleh teman-teman dan masyarakat sekitar.

Pemerintah Kota Malang dalam hal ini sangat berperan penting dalam eksistensi diri waria. Fenomena yang terjadi adalah ketika pemerintah memberikan lahan prostitusi kepada waria, akan tetapi ada beberapa anggota yang tidak mematuhi peraturan dan menyalahgunakan pemberian tersebut dengan upaya membuka kembali lahan prostitusi di tempat yang berbeda.

Ulasan di atas menyatakan bahwa upaya-upaya mempertahankan eksistensi diri waria dalam organisasi kerap dilakukan secara sistemik untuk memperkuat eksistensinya dengan harapan mendapatkan tempat dalam tatanan masyarakat. Hal demikian tidak terlepas juga dari dukungan formal yakni pihak eksternal, seperti pemerintah Kota Malang, KESRA, dan funding dari luar negeri.

\section{b. Individu}

Telepas dari zona kolektif yang membayangi eksistensi diri waria. Secara individu dari masing-masing informan penelitian kerap melakukan upaya-upaya dalam mempertahankan eksistensi dirinya sebagai waria. Upaya tersebut datang dari diri sendiri dan untuk dirinya sendiri. Seperti yang telah diketahui bahwa urbanisasi merupakan perpindahan penduduk dari desa ke kota. Urbanisasi yang biasa dilakukan waria salah satunya dikarenakan adanya ketidaknyamanan terhadap kota asal tempat tinggal mereka sebelumnya. Alasan waria tersebut pindah kota karena ruang lingkup kota sebelumnya tidak nyaman dengan faktor penolakan oleh masyarakat sekitar yang tidak menyukai eksistensi dirinya, kemudian waria tersebut dikucilkan. Didukung juga oleh kurangnya (sepi) penduduk yang membuat kegelisahan dalam faktor ekonominya.

Pernyataan tersebut menunjukkan ketdaknyamanan dalam bereksistensi secara individu dan juga terdapat kecemasan ketika berada di Kota asalnya. Sehingga upaya yang dilakukan adalah melakukan urbanisasi ke Kota Malang dengan harapan bisa mendapatkan kehidupan yang lebih baik dari sebelumnya. Berangkat dari hal tersebut, upaya lain yang mengindikasikan untuk melakukan urbanisasi adalah karena di Kota Malang memiliki komunitas waria yaitu Ikatan Waria Kota Malang (IWAMA). Adanya komunitas tersebut juga menjadi salah satu alasan untuk melakukan urbanisasi karna pada prinsipnya ketika mereka sudah menentukan pilihan dalam eksistensi dirinya, maka mereka akan mencari teman yang sama dengan mereka atau senasib.

Pada umumnya manusia membutuhkan upaya untuk mendapatkan penghasilan secara materi demi keberlangsungan hidupnya. Hal demikian terimplikasi kepada upaya-upaya dalam mempertahankan eksistensi diri sebagai waria. Secara materi, para informan 
mendapatkan penghasilan dari beberapa pekerjaan, seperti:
a) Organisasi.
b) Salon kecantikan.
c) Penari.
d) Penyanyi.
e) Pemandu karouke.
f) BO (booking order)/PSK.

Pekerjaan tersebut kerap dilakukan oleh beberapa informan peneliti. Ada pekerjaan yang layak dan tidak layak jika dalam kaca mata yang bersifat mainstream. Pekerjaan yang tidak layak tersebut seperti halnya PSK. Semua informan melakukan upaya tersebut demi keberlangsungan hidupnya secara materi.

Jika menilik lebih jauh lagi dari jenis pekerjaan BO seks tersebut. Upaya selanjutnya yang kerap dilakukan oleh informan agar tetap eksis ialah lewat jaringan internet atau media sosial. Hal demikian memang tidak dapat dipungkiri lagi di jaman modern seperti saat ini.

Seiring perkembangan teknologi, dewasa ini waria atau waria urbanisasi tersebut dalam menjaga eksistensinya yang dahulunya kerap berkeliaran di jalanan untuk mendapatkan konsumen dan mencari mangsa demi kepuasan hasratnya, akan tetapi pada era sekarang ini yang dapat dikatakan merupakan era high technology dengan kecanggihan alat komunikasi yang biasa disebut seperti smartphone dan aplikasi canggih yang terdapat di dalamnya. Kini para waria tidak perlu lagi berkeliaran di jalanan. Para waria memanfaatkan perkembangan teknologi tersebut untuk tetap eksis dalam eksistensinya. Berangkat dari hal tersebut upaya-upaya yang mereka lakukan dalam menjaga eksistensinya adalah berkomunikasi melalui smartphone tersebut kepada masyarakat luas. Komunikasi mereka dengan banyak masyarakat melalui aplikasi canggih tersebut seprti: BBM, Line, Wechat, BeeTalk, Facebook, Tweeter, Badoo, Tinder, Dan apliaksi lain sebagainya merupakan bentuk dari upaya eksistensi diri mereka. Mulai dari sebatas mencari pertemanan saja, bahkan sampai mencari konsumen dalam hal seksualitas.

Maraknya jejaring sosial membuat eksistensi waria semakin nyata dan tidak dapat dihindari. Upaya yang mereka lakukan semakin kuat karena dari media online tersebut, sehingga hampir mayoritas dari informan sudah dimiliki oleh beberapa laki-laki. Dalam artian, masing-masing informan mempunyai seseorang dalam hal pembiayaan seperti untuk modal usaha, kebutuhan sehari-hari, dan lain sebagainya.

Para informan menyebut orang yang menghidupinya itu sebagai "suami" di mana semua biaya hidup ditanggung orang tersebut. Suaminya tersebut pun didapat karena informan berupaya selalu eksis dalam jejaring sosial sehingga dengan mudah terhubung langsung dengan siapa pun.

Dari hasil penelitian yang peneliti wawancarai, suaminya tersebut bukan hanya warga negara Indonesia saja, melainkan dari luar negeri pun juga ada seperti Iran, India, Amerika, Australia, dan Jerman. Dapat disinyalir juga bahwa maraknya isu LGBT yang terjadi di Indonesia sudah tidak asing lagi sehingga dapat menimbulkan banyak tekanan dari luar yang masuk ke dalam. Bisa saja "suami” yang kerap waria sebut itu merupakan LSM dalam dan luar yang mendukung penyebarluasan LGBT di Indonesia.

Upaya dalam mempertahankan eksistensi diri sebagai waria akan terus terjadi seiring berjalannya waktu. Banyak ragam keterkaitan antarunsur fenomena eksistensi diri waria. 
Tidak menutup kemungkinan, seiring dengan perkembangan jaman akan ada upaya-upaya baru dalam mempertahankan eksistensi diri waria.

\section{Skema Hasil Penelitian}

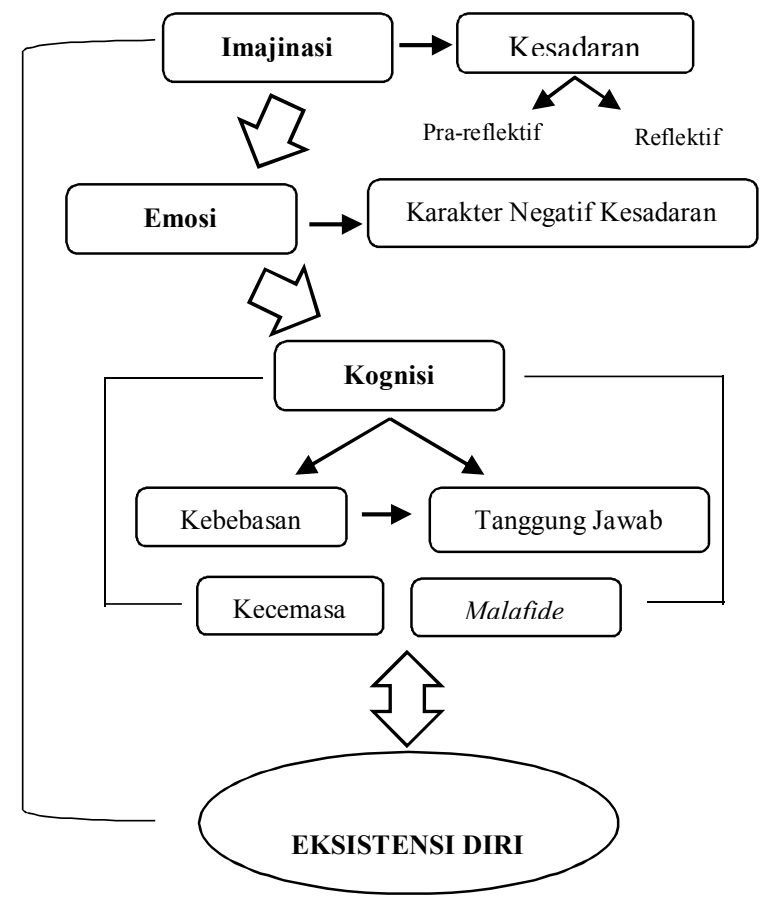

Secara konseptual dimulai dari imajinasi, emosi, dan kognisi dalam bereksistensi. Imajinasi dalam skema tersebut meliputi kesadaran pra-reflektif dan reflektif, di mana kesadaran inilah awal dari eksistensi. Setelah sudah muncul kesadaran maka akan menimbulkan emosi yang merupakan karakter negatif dari kesadaran itu sendiri. Kedua fase tersebut akan menimbulkan kognisi untuk melengkapi bagian dari eksistensi. Kognisi tersebut meliputi kebebasan dan tanggung jawab, di mana kebebasan bukanlah hal yang dapat berdiri sendiri melainkan dalam kebebasan membutuhkan tanggung jawab atas kebebasan tersebut. Ketika kebebasan dan tanggung jawab sudah ada, maka selanjutnya akan menimbulkan sisi kecemasan dalam bereksistensi dan juga malafide guna menutupi kenyataan dan kecemasan. Semua fase yang terjadi akan membuahkan hasil eksistensi diri yang utuh khususnya dalam kehidupan sosial.

\section{PENUTUP}

\section{A. Kesimpulan}

Eksistensi diri waria memiliki proses konsep yang cukup luas di mana jiwa dan raganya terbentuk melalu imajinasi, emosi, kognisi, dan aksi. Dapat dikatakan waria merupakan sosok manusia ketiga dari absolut gender dan seksualitasnya yang terbentuk melalui tekanan dan sosialisasi pada umumnya, kemudian diinternalisasi ke dalam tindakan secara normal, karena orientasi seksualitasnya berjalan normal sesuai dengan gender yang dipilihnya.

Kesadaran dalam eksistensi yang waria alami cenderung kepada kesadaran pra-reflektif di mana waria tersebut langusng terfokus kepada objek perhatiannya menjadi seorang wanita. Karakter negatif kesadaran yang dialami oleh waria tersebut juga masih melekat pada dirinya, dalam artian masih mempunyai unsur ketidakhadiran dari totalitas Ada. Eksistensi kecemasannya pun yang terjadi lebih dominan muncul dari sisi internal yakni dari diri sendiri, dalam artian dari eksistensi diri dan aktivitas yang waria lakukan masih banyak menimbulkan rasa kecemasan dari dirinya untuk dirinya sendiri dalam eksistensi sebagai waria. Sedangkan dari sisi kebebasannya, waria tersebut secara totalitas mengalami kebebasan di luar dari kausalitas yang membelenggunya. Eksistensi kebebasan yang para waria lakukan dapat dikatakan memiliki tanggung jawab atas eksistensinya secara individu dan juga secara kolektif. Namun, mereka masih memiliki malafide (bad faith) di mana aksi perilakunya selalu didorong oleh dirinya dan tekanan eksternal yang menuntutnya. 
Berdasarkan dari eksistensi dirinya, upayaupaya yang waria urbanisasi lakukan tersebut adalah lebih memilih pindah dari tempat tinggal asalnya ke kota lain dengan tujuan ingin tetap mempertahankan eksistensi dirinya. Senada dengan hal tersebut, faktor yang mendorong mereka pindah adalah karena terdapat komunitas di kota Malang yang tentu saja sangat dibutuhkan oleh waria dalam mempertahankan eksistensi dirinya karena waria tersebut menemukan sebuah kelompok yang statusnya sama dengan mereka dalam bereksistensi.

Waria urbanisasi tersebut dalam eksistensi dirinya lebih cenderung memiliki karakter sosial, sehingga upaya secara individunya ialah mereka aktif di dalam media sosial/internet dengan harapan mereka dapat menunjukkan eksistensi kepada masyarakat luas. Dengan teknologi modern tersebut mereka juga dapat penghasilan tambahan di dalam media sosial. Kendati demikian, ketika berada di dalam organisasinya mereka juga aktif dan selalu mendukung kegiatan-kegiatan sosial yang dicanangkan oleh kelompoknya tersebut. Kehidupan sosial para waria dapatkan dikatakan baik dari segi moral dan etika karena mereka memahami betul atas apa yang ada di sekitarnya, meskipun tidak semua lapisan masyarakat dapat menerimanya.

\section{B. Saran}

Untuk menjadi bahan pengembangan studi dalam berbagai disiplin ilmu akademik lainnya guna mendapatkan hasil yang komprehensif terkait dengan gender, khususnya waria atau transgender lainnya. Karena di era globalisasi seperti sekarang ini dan masa yang akan datang akan semakin banyak bermunculan gender asing yang berimplikasi kepada masyarakat luas.
Dengan kecanggihan teknologi saat ini, di mana bukan hanya benda mati saja yang bisa dipermak melainkan saat ini manusia pun juga bisa dipermak. Oleh karenanya, di sarankan kepada Pemerintah Republik Indonesia pada umumnya dan khususnya Pemerintah Kota Malang atau pemangku kebijakan lainnya agar membuat peraturan pemerintah untuk melarang atau tidak diperbolehkannya atau tidak dilegalkan kepada para transgender dalam merubah atau mengganti kelamin asli menjadi kelamin transgendernya, seperti waria, homoseksual, lesbian, dan lain sebagainya.

\section{-000-}

\section{DAFTAR PUSTAKA}

Abidin, Zainal. 2014. Filsafat Manusia, Memahami Manusia Melalui Filsafat. Bandung: PT. Remaja Rosdakarya Offset.

Bierstedt, Robert R. 1948. "The Sociology of Majority. American Sociology Review 13 hlm. 700-713

Bungin, Burhan. 2008. Penelitian Kualitatif. Jakarta: Kencana Prenada Media Group.

Centi, J Paul. 1993. Mengapa Rendah Diri?. Yogyakarta: Kansius.

Hurlock, E.1990. Psikologi Perkembangan (Suatu Pendekatan Sepanjang Rentang Kehidupan) Edisi Kelima. Jakrata: Erlangga.

Koeswinarno. 2005. Hidup Sebagai Waria. Yogyakarta: Kanisius.

Kuswarno, Engkus. 2009. Fenomenologi; Konsepsi, Pedoman, dan Contoh Penelitian. Bandung: Widya Padjadjaran.

Krestan, Birgit, 1995. Gender-Specific Participatory Approaches: Trainer's Manual. GTZ Pilot Program on Gender Issues. 
Lasswell, Marcia dan Thomas Lasswell. 1987. Marriage and The Family. Edisi Kedua. Belmont, California: Wandsworth.

Moch. Uzer Usman, 2009. Menjadi Guru Profesional. Bandung: Rosdakarya.

Oetomo, Dede. 2003. Memberi Suara Pada Yang Bisu. Cetakan Kedua. Yogyakarta: Pusaka Marwa Yogyakarta.

Palmer, D, Donald, 2007, Sartre untuk Pemula, Yogyakarta : Kanisius

Rakhmat. Jalaludin. 1996. Psikologi Komunikasi. Bandung: Remaja Rosdakarya.

Ritzer, George \& Barry Smart. 2011. Handbook Teori Sosial. Jakarta: Nusa Media.

Sartre, Jean Paul. 1956. Being and Nothingness. New York: Washington Square Press.

Smith, Jonathan A. (ed.). 2009. Psikologi kualitatif: Panduan praktis metode riset. Terjemahan dari Qualitative Psychology A Practical Guide to Research Method. Yogyakarta: Pustaka Pelajar.

Sugiyono. 2003. Metode Penelitian Bisnis. Bandung: Pusat Bahasa Depdiknas.

. 2011. Metode Penelitian Kuantitatif, Kualitatif, dan R\&D. Bandung: Alfabeta.

Sunarto, Kamanto. 2004. Pengantar Sosiologi (Edisi Revisi). Jakarta: Lembaga Penerbit FE Universitas Indonesia.

Sunaryo. 2004. Psikologi untuk Keperawatan. Jakarta: EGC

Nugroho, Wahyu Budi. 2013. Orang Lain Adalah Neraka Sosiologi Eksistensial Jean Paul Sartre. Yogyakarta:Pustaka Pelajar.

Artikel

Green, Edward J., 2016, Rural Sexuality Reasearch, The Important Forgotten - Men and Waria Living in Rural Indonesia who have Sex with Men: The Implication for HIV Education. A Reasearch Report. Executive Dean, JMC Academy, Sydney Australia: Kuliah Tamu di Universitas Airlangga Surabaya Mei 2016.
Oetomo, Dede, Dari Suara Lesbian, Gay, Bisexual, dan Transgender (LGBT) -Jalan Lain Memahami Hak Minoritas. 2008.

Renny Amelia. Konten Male Gender Role Dalam Film Animasi Walt Disney. Universitas Kristen Petra Surabaya. Diakses pada tanggal 10 Oktober 2015

\section{Tesis}

Eddy, Sugiri. Tesis. 1995. Kosa Kata Bahasa Waria di Kotamadya Surabaya (Kajian Bentuk, Makna, dan Fungsi). Bandung: Universitas Padjadjaran.

Pratiwi, Widya. Tesis. 2012. Komunikasi Bisnis Kaum Waria (Studi Fenomenologi Komunikasi Bisnis Kaum Waria di Kota Bandung). Bandung: Universitas Padjadjaran.

Soedijati, Elizabeth K. Tesis. 1996. Adaptasi dan Konflik dalam kehidupan Waria (Tinjuauan Tentang Dunia Sosial Waria di Kotamadya Bandung). Bandung: Universitas Padjadjaran.

Suyatman, Rosanti Utami Dewi. Tesis. 2010. Konstruksi Makna Sosialisasi HIV/AIDS Pada Kelompok Waria (Studi Kualitatif Tentang Konstruksi Makna Sosialisasi HIV/AIDS Pada Waria di Jawa Barat). Bandung: Universitas Padjadjaran

\section{Sumber Internet}

Makalah, Mami Hajaroh. Paradigma, Pendekatan dan Metodelogi Penelitian Fenomenologi. FIP UNY. Yogyakarta.

https://id.wikipedia.org/wiki.

http://ridhaazizi77.blogspot.co.id/epistemologifilsafateksistensialisme. 